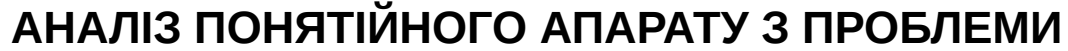 \\ ФОРМУВАННЯ СІМЕЙНИХ ЦІННОСТЕЙ У ДІТЕЙ ШКІЛЬНОГО ВІКУ \\ ANALYSIS OF THE CONCEPTUAL APPARATUS \\ ON THE PROBLEM OF THE FORMATION \\ OF FAMILY VALUES AMONG CHILDREN OF SCHOOL AGE
}

\begin{abstract}
y cтатmі розглянуто окремі аспекти поняттєвого апарату наукової проблеми формування сімейних цінностей у дітей шкільного віку. Здійснено аналіз науковоі проблеми, а саме в чому полягає сутність понять «сім'я», «цінності», «сімейні цінності». Проведено аналіз теоретичних праць вітчизняних і зарубіжних фрахівців, який свідчить, що в контексті дослідження сім'я відіграє важливу роль у розвитку людства $і \in$ найважливішим соціальним інститутом. Оволодіння дітьми сімейними цінностями, такими як любов, повага, вірність, взаємодопомога тощо, допомагає їм побудувати щасливу сім'ю, основану на любові, довірі та взаємній повазі. Можна відзначити першочерговість цього питання в модернізації системи шкільної освіти у світлі вимог Нової української школи. Сім'я володіє великими успадкованими можливостями розвивати традиційні взаємини в українській родині, основані на визнанні християнських сімейних чеснот, серед яких основними були й залишаються подружня вірність $і$ готовність піклуватися один про одного до самої смерті, турбота над дітьми, взаємна повага й любов батьків, гармонія стосунків між поколінь, спільні духовні інтереси членів сім'ї; повага до своєі родини, до історії й могил предків; працьовитість, гостинність, повага до звичаїв, відкритість для суспільного життя; багатодітні сім'ї тощо. Носієм і ядром сімейних цінностей є сама сім'я - ї ідентичність, ді окремих членів родини, взаємини між ними, їхня громадянська позиція, ставлення до навколишнього світу тощо. Результатом засвоєння сімейних иінностей повинні стати особисті переконання людини, які в результаті об'єктивної оцінки тісно пов'язані з ії чуттєво-емоційною та мотиваційно-поведінковою сфрерами. 3 одного боку, вони є основою для фрормування індивідуальних життєвих пріоритетів, а з іншого боку, вони функціонують як регулятор соціальної взаємодії з іншими людьми.
\end{abstract}

2019-19-1-35

\section{Георгадзе Т.О.,}

аспірант кафедри дошкільної освіти

і соціальної роботи

Мелітопольського державного

педагогічного університету

імені Богдана Хмельницького
Ключові слова: інститут сім'ї, освіта, сім'я, діти, виховання, цінності, сімейні цінності.

The article discusses certain aspects of the conceptual apparatus of the scientific problem of the formation of family values in children of school age. The analysis of the scientific problem, namely the essence of the concepts of family, values, family values, is carried out. The analysis of the theoretical work of domestic and foreign experts, showing that in the context of family research plays an important role in the development of mankind and is the most important social institution. Mastering children's family values (love, respect, fidelity, mutual assistance, etc.) helps them build a happy family based on love, trust and mutual consideration. One can note the priority of this issue in the modernization of the school education system in the light of the requirements of the New Ukrainian School. The family possesses great natural opportunities to cultivate traditional relations in the Ukrainian family based on the recognition of Christian family virtues, among which the main ones were and finally remain the matrimonial loyalty and willingness to care for each other until death, custody of children, parents and elders in the family, mutual the respect and love of parents, the harmony of the relations of generations, the common spiritual interests of family members; respect for his family, for the graves of ancestors; diligence, hospitality, respect for customs; openness to public life; large families, etc.; the carrier and expression of family values is the family itself - the actions of individual members, the relationship between them, their relationship to the world, and the like. The result of the assimilation of certain family values should be the personal values of a person, which, as a result of objective assessment, are closely related to its sensual-emotional and motivational-behavioral spheres. On the one hand, they are the basis for the formation of its individual life priorities, and on the other hand, they function as a regulator of social interaction with other people.

Key words: family institute, education, family, children, upbringing, values, family values.
Постановка проблеми в загальному вигляді. Протягом усієї історії людства в рамках кожної окремої культури сім'я становила особливу форму людських взаємин, зміна яких, у свою чергу, визначалася фрункціональними змінами, що переживала суспільна система. Загальна середня освіта спрямована на забезпечення всебічного розвитку особистості шляхом навчання, виховання та розвитку, які ґрунтуються на загальнолюдських цінностях і принципах, визначених Законом України «Про освіту». Щоб реалізувати головну мету освіти, необхідні взаємозв'язки між суспільством і сім'єю. Сім'я відіграє важливу роль у розвитку людства, фрормуванні й досягненні величі держав, тому дослідження інституту сім'ї має велике значення.

Аналіз останніх досліджень і публікацій. Проблему цінностей досліджували науковці Г. Ріккерт, М. Вебер, М. Шелер та інші. Питання вихо- 
вання дітей відображено в працях вітчизняних науковців, таких як Г. Сковорода, А. Макаренко, В. Сухомлинський, С. Русова, К. Ушинський та інші. Працями видатні українські науковці: Роман М. Шеремета, О. Турчинов, М. Кулеба, П. Угурян, О. Романенко, С. Грунтовський, А. Буковинський, І. Сіданіч, О. Мельник, Р. Кухарчук, Т. Кравченко, Л. Канішевська, І. Білоцерківець, В. Олійник та інші - зробили вагомий внесок у дослідження питань інституту сім'ї, сімейного виховання, ціннісних орієнтацій молоді у сфері шлюбно-сімейних взаємин в умовах суспільних транссрормацій.

Мета статті полягає у висвітленні понятійного апарату наукової проблеми формування сімейних цінностей дітей шкільного віку.

Виклад основного матеріалу. У сучасному світі в молоді недостатньо розвинені навички життєвого самовизначення. Беручи шлюб, молодь не обдумує своє рішення настільки серйозно, наскільки вимагає це питання. Виходячи із цього, необхідно шукати шляхи вирішення цієї проблеми. При цьому важливим стає ціннісний підхід. Сутність цього підходу полягає в розгляді сім'ї як цінності, усвідомленні реальної досяжності цієї цінності в сучасному світі й передбаченні її подальшого поширення як складника прогресу. Сім'я $€$ найважливішим соціальним інститутом, оскільки відображає систему цінностей і зв'язків: шлюбних і родинних, господарських і правових, етичних і психологічних. За даними наукових досліджень Ради молодих вчених при Міністерстві освіти і науки України, в порядку пріоритетів основними цінностями сучасної молоді є сімейні, духовні, суспільні й егоїстичні.

Внутрішньо молодь насамперед хоче мати щасливу родину, але вона не розуміє, як її побудувати, через десріцит духовних знань. Україна на першому місці в Європі за кількістю розлучень: за даними Держкомстату, на 295 тисяч укладених шлюбів у країні припадає 130,7 тисяч розлучень. Тобто розлучаються 44,3\% подружніх пар. А якщо взяти до уваги цивільні шлюби, які також розпадаються, то рівень розлучень в Україні, за даними фахівців, сягає 61\%. Отже, розпадається більше як половина пар! Це найвищий показник у Європі [5, с. 129].

Ми вважаємо, що запорукою позитивних показників освіти будуть напрями діяльності нашої держави, які передбачатимуть собою необхідність ужити заходів щодо підвищення ролі сім'ї, зміцнення моральних і матеріальних засад сімейного життя; забезпечити розроблення програм щодо підготовки молоді до подружнього життя й фрормування відповідального батьківства.

Батьківська позиція - психологічна та виховна спрямованість матері й батька, основана на свідомій чи неусвідомлюваній оцінці дитини, що виражається в певних способах і нормах взаємодії з нею. Батьківська позиція має такі ознаки: адекватність (найбільш близька до об'єктивної оцінка психологічних і характерологічних особливостей дитини, побудова виховного впливу на основі такої оцінки); гнучкість (здатність змінювати методи й фрорми спілкування та впливу на дитину відповідно до ії вікових особливостей, конкретних ситуацій); перспективність (спрямованість виховних зусиль на майбутнє згідно 3 вимогами, які поставить перед дитиною подальше життя) [6, с. 88].

Зміст виховання майбутнього сім'янина 3 дошкільного до студентського віку охоплює фрормування ціннісно-позитивного образу сім'ї та сімейних стосунків, започаткування морально-трудового виховання майбутнього сім'янина (дошкільний вік); морально-етичне виховання, розвиток норм і зразків бажаної поведінки в сім'ї, суспільстві (молодший шкільний вік); морально-статеве виховання, фрормування культури стосунків (середній шкільний вік); формування готовності до шлюбу й сімейного життя (старший шкільний вік); систематизація знань про сім'ю і шлюб, самовиховання майбутнього сім'янина (студентський вік).

Освіта - це соціальний інститут, що є сукупністю певних установ, осіб, які забезпечені спеціальними матеріальними засобами і здійснюють конкретні соціальні фрункції; з іншого боку, набір, система ідей, правил, положень, стандартів, норм діяльності, поведінки людей у ситуаціях освітянського життя [8, с. 68].

Виховання - вплив на людину всього суспільства й усієї діяльності, яка містить у собі не лише позитивну спрямованість, а й конфлікти та протиріччя; тут особистість може не тільки фрормуватися під впливом соціального середовища, а й деформуватися або, навпаки, загартовуватися в боротьбі з труднощами [8, с. 67].

Ціннісні орієнтації особистості - соціальні цінності, що виступають для особистості як цілі життя й основних засобів досягнення цих цілей, у силу цього набирають фрункції важливих регуляторів особистості [8, с. 56].

Сім'я - соціальне об'єднання, члени якого пов'язані шлюбними взаєминами, взаємодопомогою, моральною відповідальністю та спільністю побуту; соціальний інститут, який характеризується соціальними визначеннями, санкціями, прикладами поведінки, правами й обов'язками, що регулюють відносини між чоловіком і жінкою, батьками та дітьми [8, с. 64].

Сім'я - соціальна група, яка складається з чоловіка та дружини й дітей (у тому числі й усиновлених), а також кровних родичів чоловіка та дружини, що перебувають у спорідненості щодо одне до одного (універсальний словник).

Сім'я - це сукупність близьких родичів, що разом мешкають (тлумачний словник Даля).

Сім'я - група людей, які пов'язані родинними чи подібними взаєминами, в якій дорослі беруть 
на себе відповідальність за турботу й виховання своїх рідних чи всиновлених дітей (енциклопедія «Сім'я»).

Сім'я $€$ первинним та основним осередком суспільства. Сім'ю становлять особи, які спільно проживають, пов'язані спільним побутом, мають взаємні права й обов'язки. Сім'я створюється на підставі шлюбу, кровного споріднення, усиновлення, а також на інших підставах, не заборонених законом і таких, що не суперечать моральним засадам суспільства (Сімейний кодекс України (пп. 1, 2, 4 ст. 4)).

Сім'я $€$ соборною частиною суспільного організму; родина має у своїй основі духовне ядро; в основі сімейного виховання лежить сімейний аспект змісту виховання; сім'я володіє великими природними можливостями виховання; традиційно стосунки в українській родині будувалися на визнанні християнських сімейних чеснот, серед яких головними були й, зрештою, залишаються подружня вірність і готовність піклування одне про одного до смерті, опіка над дітьми, над батьками і старшими в сім'ї, взаємна повага й любов батьків, гармонія стосунків поколінь, спільність духовних інтересів членів сім'ї; пошана до свого роду, до могил предків; працьовитість, гостинність, дотримання звичаїв; відкритість щодо суспільного життя; багатодітність тощо; носієм і виразником сімейних цінностей $€$ сама родина - вчинки окремих членів, стосунки між ними, їхнє ставлення до світу тощо [2, с. 46].

Суспільні відносини своїми численними, в тому числі безпосередніми й опосередкованими, формами впливають на інститут сім'ї, чи правові, релігійні, атеїстичні, політичні, чи морально-естетичні аспекти.

Мораль - внутрішнє право, спосіб поведінки, опосередкований суб'єктивними чинниками: свідомістю, совістю, критичними міркуваннями. Оскільки свобода $є$ вихідне гасло такого суспільства, моральність посідає значне місце в його житті. ІІї головні категорії - намір і вина, добро і совість. Нарешті, в суспільстві існує великий прошарок відносин, які є водночас і внутрішньо притаманними індивідові, і зовнішніми стосовно нього: це - звичаї, традиції, природні права, закони. Системою звичаїв охоплюються три головні сфери суспільства: сім'я - місце народження й виховання людини; громадянське суспільство - система матеріальних і виробничих відносин, у якій кожен переслідує приватну мету; держава - організація, яка утворює й підтримує життя народу як цілого, оберігає його від розпаду [7].

Цінність - значимість, яку люди надають речам чи явищам і яка лежить в основі ставлення до них (вибору, надання переваги тощо). Цінність має місце лише в актах оцінювання, коли ми вибираємо, вибудовуємо ієрархічну структуру цінностей. Цінності мотивують поведінку людей [4].
Цінність - це будь-який об'єкт, у тому числі й ідеальний, який має життєво вагоме значення для окремої особистості, групи людей чи всього суспільства; це ідеали, виражені в естетичних орієнтирах виховання й навчання: істина, добро, особистість, користь, свобода, любов, творчість, вибір тощо; ідеали, до яких варто прагнути, ставитися з повагою, визнанням і шануванням.

Цінності виникають під час практичної діяльності людей, коли вони не тільки пізнають властивості природних і соціальних явищ, а й намагаються дати їм оцінку 3 погляду встановлення їх корисності/шкідливості для свого життя. Тобто в понятті «цінність» відображена виявлена й усвідомлена здатність певних об'єктів реальності задовольняти важливі потреби групи людей чи окремої особистості [1, с. 56].

Історично виникнення цього поняття та його еквівалентів у різних мовах пов'язане з процесом зміни оціночних суджень, коли 3 прикметників, які свідчили про належність людини до вищих верств населення («знатний», «шляхетний»), виникло поняття «цінний» як оцінка значущості для суб'єкта деякої абстрактної ідеї чи матеріального предмета. Незважаючи на те що слово «цінність» використовувалося людьми 3 часів глибокої давнини, в науковий обіг воно введено тільки в другій половині XIX ст. німецьким фрілософом Р. Лотце.

За радянських часів у вітчизняній науковій літературі термін «цінність» тривалий час уживався, оскільки вважався «дрібнобуржуазним» поняттям. Проблему цінностей порушено на початку 60-х рр. XX ст. фрілософом В. Тугариновим у праці «Про цінності життя та культури».

У вітчизняній педагогічній літературі першим ідею про необхідність ціннісного наповнення змісту освіти висловив В. Сухомлинський, який стверджував, що в навчально-виховному процесі необхідно транслювати молодій людині провідні суспільні цінності, допомагати їй опанувати їх, відпрацьовувати особисте ставлення до того, про що вона дізнається та пізнає, «вчити людину правильно жити, правильно чинити, правильно ставитися до людей і до самого себе». Видатний педагог не тільки зробив освітні цінності стрижневою категорією в усіх працях, а й постійно підкреслював, що справжні цінності мають загальнолюдський характер.

Говорячи про місце сім'ї, сімейних цінностей поряд $з$ освітою в житті громадян, Українська Конституція передбачає таке.

Стаття 51 говорить: «Шлюб ґрунтується на вільній згоді чоловіка і жінки. Кожен із подружжя має рівні права і обов'язки у шлюбі та сім'ї. Батьки зобов'язані утримувати дітей до їх повноліття. Повнолітні діти зобов'язані піклуватися про своїх непрацездатних батьків. Сім'я, дитинство, материнство і батьківство охороняються державою» [3]. 
Опанування дітьми сімейних цінностей (кохання, повага, вірність, взаємодопомога тощо) допомагає їм побудувати щасливу родину на основі любові, довіри й взаємопіклування. Необхідно також вести мову про ціннісну свідомість і ціннісні орієнтації дітей шкільного віку.

Ціннісні орієнтації - вибіркова, відносно стійка система спрямованості інтересів і потреб особистості, зорієнтована на певний аспект соціальних цінностей; ціннісні орієнтації задають аксіологічний вектор життєдіяльності людини на ідеальному рівні. Ставлення педагога до фрактів, явищ навколишньої дійсності з огляду на їх важливість, значущість; ставлення до матеріальних і духовних цінностей, система її установок, переконань, переваг, що виражаються в поведінці.

Ціннісна свідомість - це сукупність орієнтирів на певні соціальні цінності: ідеали, норми, традиції, звичаї тощо. Ціннісна свідомість зумовлює спосіб включення дитини в різні форми суспільної діяльності й характер, спрямованість людської активності.

Результатом засвоєння визначених сімейних цінностей мають стати особистісні цінності людини, які, будучи результатом об'єктивного оцінювання, тісно пов'язані 3 їі чуттєво-емоційною й мотиваційно-поведінковою сорерами. 3 одного боку, вони $є$ основою для фрормування її індивідуальних життєвих пріоритетів, а з іншого - виконують фрункцію регулятора соціальної взаємодії з іншими людьми.

Висновки. Останніми десятиріччями цінність перетворилася у важливий об'єкт досліджень у різних наукових галузях: фрілософії, соціології, психології, історії, етики, педагогіки тощо. Специфічною відмінністю ціннісної проблематики в педагогіці $€$ її прикладний характер, оскільки основними завданнями педагогічних наукових розвідок $€$ не тільки теоретичне обґрунтування цінностей, які мають стати підґрунтям для реалізації навчально-виховного процесу в освітньому закладі, а й визначення ефективних засобів їх трансляції молоді. Носієм і виразником сімейних цінностей є сама родина. Домінуючими в рейтингу ціннісних пріоритетів української молоді залишаються міцна сім'я, міцне здоров'я та благополуччя дітей, матеріальний добробут. Традиційно стосунки в українській родині будувалися на визнанні християнських сімейних чеснот, серед яких головними були й, зрештою, залишаються подружня вірність і готовність піклуватися одне про одного до смерті, опіка над дітьми, над батьками і старшими в сім'ї, взаємна повага та любов батьків, гармонія стосунків поколінь, спільність духовних інтересів членів сім'ї, пошана до свого роду.

Результатом засвоєння визначених сімейних цінностей мають стати особистісні цінності людини, які, будучи результатом об'єктивного оцінювання, тісно пов'язані 3 їі чуттєво-емоційною й мотиваційно-поведінковою сферами. 3 одного боку, вони є основою для фрормування ії індивідуальних життєвих пріоритетів, а з іншого - виконують фрункцію регулятора соціальної взаємодії 3 іншими людьми. Подальшого розвитку набули питання важливості роботи формування сімейних цінностей у дітей шкільного віку.

\section{БІБЛІОГРАФІЧНИЙ СПИСОК:}

1. Вища освіта та Європейський простір / В. Крижко, М. Елькін, О. Старожко, К. Тільчарова, О. Грицайова. Бердянськ : Видавець Ткачук О.В., 2015. 448 c.

2. Георгадзе Т.О. Сім'я як джерело захисту i впливу на формування сімейних цінностей сучасної української молоді. Науковий часопис Національного педагогічного університету імені М.П. Драгоманова. Серія 5 «Педагогічні науки: реалії та перспективи» : збірник наукових праць / М-во освіти і науки України, Нац. пед. ун-т імені М.П. Драгоманова. Київ : Вид-во НПУ імені М. П. Драгоманова, 2018. Вип. 61. 374 с. C. $45-48$.

3. Конституція України. Розділ II «Права, свободи та обов'язки людини і громадянина». URL: https://www.president.gov.ua/ua/documents/ constitution/konstituciya-ukrayini-rozdil-ii.

4. Філософрія : мультимедійний навчальний посібник / Національна академія внутрішніх справ, кафедра фрілософії права та юридичної логіки. URL: https://www.naiau.kiev.ua/books/filosofia-30012017/ info/slovnyk.html.

5. Ресормація: успіх Європи і шанс для України : колективна монограсрія / Р.М. Шеремета, О. Романенко, В.Л. Сміт та ін. ; за редакцією Р.М. Шеремети та О. Романенко ; Університет менедж. освіти. Київ : Самміт-Книга, 2017. 256с.

6. Садова Т.О., Дем'яненко А.М. Відповідальне батьківство - основа майбутньої освіти. Teoretyczne $i$ praktyczne aspekty rozwoju wspołczesnej nauki : Zbior artykułow naukowych. Konferencji Miedzynarodowej Naukowo-Praktycznej (30.03.2017-31.03.2017). Warszawa : Wydawca: Sp. z 0.0. «Diamond trading tour», 2017. C. 88-89.

7. Ціннісні орієнтації сучасної української молоді : стенограма парламентських слухань від 02.11.2016. URL: http://gska2.rada.gov.ua/zakon/new/ par_sl/sl021116.htm.

8. Тематичний словник-довідник 3 соціології / за ред. В.В. Кохана ; укл. А. Александровська, $€$. Буга, Ю. Ткачук та ін. Чернівці : Чернівецький нац. ун-т, 2009. 122 c. 